\title{
MENINGKATKAN PERKEMBANGAN MOTORIK KASAR ANAK MELALUI METODE TARI MANUK DADALI
}

\author{
Abdul Muiz Rouf, Ma \\ Universitas Muhammadiyah Cirebon
}

\begin{abstract}
ABSTRAK
Penelitian tindakan kelas ini merupakan salah satu upaya yang bertujuan menghantarkan anak kelompok B TK Sejahtera Karangmulya Plumbon Cirebon pada pencapaian perkembangan fisik motorik anak secara optimal melalui penerapan metode tari manuk dadali pada kegiatan pembelajaran seni ekspresif anak.

Metode yang digunakan dalam penelitian ini adalah penelitian tindakan kelas menggunakan skenario kerja dan prosedur tindakan dengan mengadaptasi model Kemmis dan McTaggart, yaitu: (1) perencanaan tindakan, (2) pelaksanaan tindakan, (3) observasi, dan (4) refleksi

Tindakan perbaikan pembelajaran menggunakan metode tari manuk dadali pada penelitian ini, menunjukkan bahwa rata-rata kemampuan seni ekspresif anak dalam aspek perkembangan fisik motorik kelompok B TK Sejahtera Karangmulya Plumbon Cirebon mulai dari pra siklus sampai pada tindakan siklus I dan II meningkat berturut-turut dari rata-rata $34.60 \%$ pada pra tindakan, $51.75 \%$ pada siklus I, dan $78.95 \%$ pada siklus II, demikian juga presentasi ketuntasan belajar dilihat dari pencapaian perkembangan aspek fisik motorik anak meningkat optimal berturut turut dari $31,60 \%$ pada pra siklus dengan 13 anak yang masih dinyatakan belum berkembang, 89,47\% pada siklus 1 dengan 2 anak yang masih dinyatakan belum berkembang dan 100\% ketuntasan belajar pada aspek perkembangan fisik motorik anak berkembang optimal.
\end{abstract}

Kata Kunci; Motorik Kasar, Seni Tar i

Dalam rangka mengoptimalkan

Pendahuluan

Pendidikan anak usia dini adalah suatu upaya pembinaan yang ditunjukan kepada anak sejak lahir sampai dengan anak berusia 6 tahun yang dilakukan melalui pemberian rangsangan pendidikan untuk membantu pertumbuhan dan perkembangan jasmani dan rohani agar anak memiliki kesiapan dalam memasuki pendidikan lebih lanjut. perkembangan anak melalui pendidikan anak usia dini, program pendidikan harus disesuaikan dengan karakteristik anak yang mempunyai pengalaman dan pengetahuan yang berbeda. Manurut Santoso dalam Liaamalia (2017) bahwa program untuk anak harus memperhatikan seluruh aspek perkembangan anak serta disesuaikan dengan kebutuhan, minat, dan kemampuan anak.. Demikian juga kemampuan guru 
dalam pengelolaan kelas belajar yang menyenangkan dan menarik dapat menumbuhkan minat belajar dalam berhitung dan dapat menghantarkan anak mencapai tujuan pembelajaran sebagai mana yang diharapkan.

Pemupukan minat anak sejak dini akan member kontribusi yang sangat berarti pada perkembangan anak masa depan. Berbagai minat perlu dilatih terutama melalui pembelajaran tari. Karena pembelajaran tari dapat memberikan pengalaman belajar yang menyenangkan bagi anak. Pendidikan seni tari di sekolah Taman KanakKanak merupakan bagian dari proses pembentukan individu yang utuh sesuai dengan tujuan pendidikan nasional. Tari anak usia dini harus disesuaikan dengan gerak motorik anak usia dini, yaitu meliputi kemampuan motorik halus dan kasar secara sederhana. Tarian ini mencakup gerakan-gerakan tubuh yang dapat di lakukan anak, misalnya gerak kepala (tengadah, menoleh, memutar, dan menggeleng-gelengkan kepal). Gerak badan (tegak, miring, membungkuk, goyang, dan memutar), gerak tangan (merentang, mengayun, mengangkat, menyiku, memutar, menunjuk, mengacung, bertepuk, dan sebagainya). Bentuk tari pada anak usia dini harus memperhatikan karakteristik gerak anak usia dini, yaitu: gerak menirukan, dalam bermain anak senang menirukan daripada yang di amatinya, gerak manipulasi (perlakuan) anak-anak secara spontan melakukan gerakan berdasarkan objek yang diamatinya sesuai dengan keinginan melalui gerakan-gerakan yang disenanginya, dan gerak bersahaja, maksudnya dalam melakukan gerak anak melakukan gerak sangat sederhana, tanpa dibuatbuat dan apa adanya. Ungkapan gerak anak pada umumnya memiliki karakter lincah, cepat, dan menggambarkan kegembiraan. Fungsi tari pada anak usia dini bukan sebagai media upacara ritual, hiburan atau tontonan seperti fungsi tari secara umum, pada tari anak usia dini lebih berfungsi sebagai media ekspresi dan kreativitas. Tema tari anak usia dini disesuaikan dengan perkembangan psikologi anak usia dini, tema yang cocok diantaranya tentang lingkungan sekitar, perilaku manusia, kegiatan kerja, gerak binatang, perilaku tokoh-tokoh pada dongeng dan sebagainya.

Dengan anak belajar seni tari maka akan terjadi perkembangan dari aspek pada diri anak termasuk aspek fisik motorik kasar. Perkembangan motorik kasar anak pada umumnya sangat aktif, mereka telah memiliki penguasaan terhadap tubuhnya dan sangat menyukai kegiatan-kegiatan yang dilakukan sendiri. Keterkaitan antara kemampuan motorik kasar anak dengan kecerdasan jamak (multiple intelligence) cukup relevan pada aspek kecerdasan kinestetik tubuh. Motorik kasar adalah aktivitas fisik atau jasmani dengan menggunakan otot-otot besar seperti lengan, otot tangan, otot bahu, otot tungkai, otot pinggang, dan otot perut yang dipengaruhi kematangan fisik anak. Motorik kasar dilakukan dalam bentuk berjalan, berjinjit, melompat, meloncat, berlari, berguling. Perkembangan motorik setiap anak berbeda-beda sesuai dengan usia dan perkembangan anak. 
Permasalahan perkembangan fisik motorik kasar anak di kelompok B TK Sejahtera Sejahtera Karangmulya kecamatan Plumbon Kabupaten Cirebon berdasarkan hasil observasi menyebutkan bahwa; anak kelompok B TK Sejahtera yang berjumlah 19 anak menunjukkan bahwa sebanyak 9 anak $33 \%$ masih mengalami kesulitan dalam melakukan gerak tubuh untuk melatih kelenturan, kelincahan, dan keseimbangan. Selain itu ada 6 anak dengan persentase $40 \%$ masih kurang lincah pada gerakan berjalan kesamping sambil kepak geser, dan ada 4 anak dengan persentase $27 \%$ yang mampu melakukan gerakan dengan lincah. Dalam melakukan gerakan kesamping sambil kepak geser masih memerlukan bantuan gurunya. Demikian juga dalam gerakan berjalan kesamping sambil kepak geser, anak belum menggunakan kakinya dengan baik. Anak masih kesulitan menjaga keseimbangan tubuhnya. Hal ini juga dikarenakan kondisi ruang kelas yang sempit, sehingga menghambat anak untuk bergerak bebas.

Kemampuan motorik kasar anak usia 5-6 tahun seharusnya sudah mampu melakukan gerakan tubuh secara terkoordinasi anak melatih kelenturan, keseimbangan, dan kelincahan. Untuk meningkatkan kemampuan motorik kasar anak dan untuk mengembangkan keterampilan seni tari anak kelompok B di TK Sejahtera dilakukan kegiatan pembelajaran menggunakan metode gerak tari dengan mengambil focus pada materi kreasi tari Manuk Dadali, mengingat gerakan pada kreasi tari manuk dadali ini lebih mudah di bandingkan dengan tari kreasi yang lain, selain itu iringan lagu yang menyenangkan untuk anak dengan bentuk kostum yang menarik untuk Anak Usia Dini. Tari Manuk Dadali berguna untuk mendemonstrasikan suatu keterampilan motorik, melatih keseimbangan saat bergerak, melatih, mendidik, dan membentuk karakter kepribadian Anak Usia Dini. Dengan stimulasi yang dilakukan melalui metode tari Manuk Dadali ini diharapkan kemampuan motorik kasar siswa dapat mengalami peningkatan.

\section{A. Perkembangan Motorik Kasar dan Seni Tari AUD}

Motorik kasar adalah bagian dari aktivitas motorik yang mencakup keterampilan otot-otot besar, gerakan ini lebih menuntut kekuatan fisik dan keseimbangan, gerakan motorik kasar melibat kan aktivitas otot tangan, kaki, dan seluruh anak, gerakan ini mengandal kan kematangan dalam koordinasi, berbagai gerakan motorik kasar yang di capai anak sangat berguna bagi kehidupannya kelak, seperti merangkak, berjalan, berlari, melompat atau berenang. Menurut Hurlock (1978) motorik kasar adalah gerakan tubuh yang menggunakan otot-otot besar atau sebagian besar atau seluruh anggota tubuh yang dipengaruhi oleh kematangan anak itu sendiri. Dorong anak berlari, melompat, berdiri di atas satu kaki, memanjat, bermain bola, mengendarai sepeda roda tiga. Perkembangan motorik adalah perkembangan pengendalian gerakan jasmaniah melalui kegiatan pusat saraf, urat saraf, dan otot yang terkoordinasi Untuk pengembangan pengendalian gerak motorik tersebut salah satunya melalui kegiatan tari 
Pendidikan seni tari sangat berpengaruh pada perkembangan anak yang ditandai dengan perkembangan motorik kasar dan halus anak, pola bahasa dan perkembangan sosial dan emosional anak. Bahkan, penelitian yang dilakukan oleh Dewi Yuliana (2011), menjelaskan bahwa dengan belajar seni tari, anak dengan sendirinya telah mendapatkan kegiatan seni tari, terkendali sikapnya, tidak nakal dan sopan santun yang baik. Pendidikan seni tari anak usia dini adalah suatu proses atau usaha dalam mendidik anak agar mampu mengontrol dan menginterpretasikan gerak tubuh, memanipulasi benda-benda dan menumbuhkan harmoni antara tubuh dan pikiran. Pendidikan tari anak usia dini menekankan pada gerak, keharmonisan gerak, mengontrol gerak motorik kasar maupun motorik halus yang dapat mengembangkan kecerdasan anak, Yetti dalam Indah J (2015).

Tujuan pembelajaran seni tari adalah mengenalkan seni tari pada anak-anak, sehingga mereka merasa suka dan tertarik untuk mempelajarinya, dan dalam proses pembelajaran nya anak-anak dapat mengekspresikan kreativitas nya melalui gerak yang ia ciptakan sendiri. Gerak adalah bagian dari keberadaan alamiah anak usia dini. Anak-anak suka berlari meloncatloncat, menghempaskan tubuhnya di dalam kelas sambil berguling-guling dan lainnya. Akan tetapi, yang harus diperhatikan adalah bukan berarti anak dengan bebas atau semuanya sendiri melakukan gerakan-gerakan yang mungkin membahayakan dirinya sendiri dan mengganggu teman nya yang lain, namun juga harus ada control dari pendidik.

Pendidikan seni tari bagi anak-anak, pada dasarnya mempunyai tujuan agar supaya anakanak dapat belajar menari yang sesuai dengan tingkat kemampuannya dan kodrat kejiwaannya. Sehingga secara kreatif, tubuh sebagai alat ekspresi, mampu mengungkapkan kembali segala imajinasi dan fantasi anak. Gerakan dalam seni tari anak-anak tentunya mempunyai perbedaan dengan seni tari orang dewasa. Gerakan tersebut haruslah mewakili dunia anak, yang penuh dengan kegembiraan dan kesenangan. Bentuk gerak yang sesuai dengan karakteristik anak-anak, adalah gerak yang tidak sulit atau gerak yang sederhana. Namun demikian, cirri khas dari anak-anak, adalah tidak bisa diam terlalu lama, aktif, lincah, dan cepat, yang menggambarkan kegembiraan dan kesenangan. Dalam hal ini, guru harus memperhatikan keduanya (gerak yang sederhana dan gerak yang lincah dan aktif) dalam mencipta gerakan tari.

Musik adalah hal yang paling disukai anak. Tiada hari tanpa musik dalam pembelajaran di kelas maupun di luar kelas. Anak larut dalam alunan lagu yang semangat dengan bertepuk tangan atau berjingkrak. Begitu halnya dengan seni tari. Dengan iringan musik, anak-anak menjadi lebih semangat dalam melakukan gerakan tari. Tentunya, musik iringan seni tari yang sesuai dengan karakteristik anak-anak adalah musik yang menggambarkan kesenangan dan kegembiraan, misalnya lagu lihat kebun ku, Pada Hari Minggu, Naik Kereta Api, dan lain-lain. 
Metodologi

Penelitian ini merupakan Penelitian Tindakan Kelas (Classroom Action Research) yang biasa disingkat dengan PTK, Penelitian Tindakan Kelas ini berfokus pada upaya untuk mengubah kondisi rill sekarang ke arah kondisi yang diharapkan. Penelitian Tindakan Kelas ini dilakukan untuk meningkatkan perkembangan motorik kasar anak dengan metode tari manuk dadali.

Tujuan dari penelitian tindakan kelas menurut Suhardjono dalam Dedi Supriadi, (2006) adalah: 1) meningkatkan mutu, isi, masukan, proses serta hasil pendidikan dan pembelajaran di sekolah; 2) membantu guru dan tenaga kependidikan mengatasi permasalahan pendidikan di dalam dan di luar kelas; 3) meningkatkan professional guru dan tenaga kependidikan; 4) Mengembangkan budaya akademik di lingkungan sekolah sehingga untuk menciptakan sikap proaktif dalam melakukan perbaikan mutu pembelajaran dan pendidikan secara berkelanjutan

Pelaksanaan penelitian ini akan dilakukan dalam 2 siklus Perbaikan pembelajaran dilaksanakan dalam proses pengkajian berdaur yang terdiri dari 4 tahap yaitu : (a) Perencanaan (planning) Sebelum melakukan penelitian tindakan kelas, peneliti terlebih dahulu menyusun rencana kegiatan harian (RKH), membuat skenario penerapan pola lantai, Menyiapkan gerakan dan lagu manuk dadali, menyiapkan alat atau perangkat seni, peneliti juga membuat kesepakatan dengan observer untuk menentukan fokus observasi dan kriteria yang akan digunakan. (b)
Tindakan (Acting) Pelaksanaan yang merupakan penerapan isi rancangan yaitu mengenai tindakan yang akan dilakukan di kelas. Pada tahap ini guru harus mengingat dan mentaati apa yang sudah dirumuskan dalam rancangan. (c)Pengamatan / Observasi Selama proses pembelajaran, peneliti meminta bantuan kepada rekan guru atau teman sejawat untuk mengamati kegiatan yang akan dilakukan anak didik dan mengumpulkan data berdasarkan instrument lembar observasi yang telah disiapkan. (d) Refleksi Berdasarkan masukan teman sejawat guru, peneliti melakukan refleksi terhadap kegiatan pembelajaran yang akan dilaksanakan, Antara lain dengan berusaha mengingat kembali cara pembelajaran yang telah dilaksanakan dan keterlibatan serta ketertarikan anak pada saat kegiatan pembelajaran yang telah dilakukan, dan guru berusaha melakukan perbaikan untuk dilaksanakan pada siklus berikutnya. Dari kegiatan ini akan diperoleh gambaran tentang keaktifan siswa, suasana pembelajaran, serta peningkatan perkembangan seni ekspresif anak.

\section{Hasil Penelitian}

Hasil tindakan perbaikan pembelajaran menggunakan metode tari manuk dadali pada penelitian ini, menunjukkan bahwa rata-rata kemampuan seni ekspresif anak dalam aspek perkembangan fisik motorik kelompok B TK Sejahtera Karangmulya mulai dari pra siklus sampai pada tindakan siklus I dan II meningkat berturut-turut dari rata-rata $34.60 \%$ pada pra tindakan, $51.75 \%$ pada siklus I, dan $78.95 \%$ pada siklus 
II, demikian juga presentasi ketuntasan belajar dilihat dari pencapaian perkembangan aspek fisik motorik anak meningkat optimal berturut turut dari $31,60 \%$ pada pra siklus dengan 13 anak yang masih dinyatakan belum berkembang, $89,47 \%$ pada siklus 1 dengan 2 anak yang masih dinyatakan belum berkembang dan $100 \%$ ketuntasan belajar pada aspek perkembangan fisik motorik anak berkembang optimal.

\section{Kesimpulan}

Pelaksanaan tindakan pembelajaran melalui penerapan metode tari ini terdiri dari 2 siklus. Dalam kegiatan penelitian tindakan kelas ini semua langkah yang dilakukan mengikuti prosedur penelitian tindakan kelas model Kemmis yang terdiri dari kegiatan perencanaan (planning), pelaksanaan tindakan (actuating), (observing) pengamatan Refleksi/evaluasi (Reflecting) berjalan sesuai prosedur yang ditetapkan Hasil tindakan dapat disimpulkan bahwa penerapan metode tari pada kegiatan tindakan mulai dari siklus I dan II membawa perubahan pada peningkatan perkembangan perkembangan fisik motorik anak secara optimal 


\section{Daftar Pustaka:}

Andi Prastowo, 2011 Perilaku Sikap Orang Tua yang Harus di Hindari terhadap Anak. Penerbit Buku Biru, Jogjakarta

Anna Poedjiadi, 2007 Filsafat Ilmu, Universitas Terbuka-Jakarta

Arikunto, Suharsini 2006 Metode Penelitian. Jakarta: Rineka Cipta.

Dedi Supriadi, 2006 Aktivitas Mengajar Anak TK. Penerbit Kartasis, Bandung

Depdiknas, 2010, Pedoman Penerapan Pendekatan BBCT dalam Pendidikan Anak Usia Dini. Jakarta: Depdiknas. Depdiknas Pedoman Pembelajaran Bidang Pengembangan Fisik/ Motorik di Taman Kanak-Kanak. Jakarta: Depdiknas.

Depdiknas, 2013 Acuan Menu Pembelajaran Pada Pendidikan Anak Usia Dini ( Menu Pembelajaran Generik ). Jakarta: Depdiknas.

Elis Supartini, Dkk. 2016 Pedagogik : Karakteristik Anak Usia Dini Profesional: Masalah dan Penanganan Anak Usia Dini, Direktorat Guru dan Tenaga Kependidikan , Jakarta

Gerard Masterson, Jr, 2006. Membekali anak Supaya Tumbuh Sehat, aman dan bijak. Prestasi pustaka anak. Jakarta-Indonesia

Hurlock, Elizabeth. 1978. Perkembangan Anak Vol 2. Jakarta: Erlangga.

Indah Juniasih. 2015. Peningkatan Kreativitas Gerak Melalui kegiatan tari pendidikan berbasis cerita Tarita (online) Tersedia: http//journal.unnes.ac.id/sju/index.php/jst

Jojoh Nurdiana. 2016 Pedagogik : Kurikulum dan Program Pembelajaran TK Profesional : Indikator Capaian Perkembangan Anak TK, Direktorat Guru dan Tenaga Kependidikan, Jakarta

Karen Mc.gill 2007. Mendidik Bayi Cerdas di Tahun Pertama. PT. Prestasi Pustakarya-Jakarta

Kusnadi, 2009 Penunjang Pembelajaran Seni tari. PT. Tiga Serangkai Pustaka Mandiri. Jakarta

Liaamalia, 2017 Aspek Perkembangan Anak Usia Dini, Tersedia: http://kbamalia.blogspot.co.id/2017/12/6-aspek-perkembangan-anak-usia-dini.html

Lukmanul Hakim, 2009, Perencanaan Pembelajaran, Bandung. CV. Wacana Prima

Masitoh,Dkk. 2006 Strategi Pembelajaran TK. Jakarta : Universitas Terbuka

Novi Mulyani, 2016 Pendidikan Seni tari Anak Usia Dini, Gava Media, Yogyakarta

Peraturan Menteri Pendidikan dan Kebudayaan Republik Indonesia Nomor 146 Tahun 2014 Tentang Kurikulum 2013 Pendidikan Anak Usia Dini. Jakarta: Depdikbud 
Rini Hildayani,dkk. 2004 Psikologi Perkembangan Anak. Universitas Terbuka. Jakarta

Dewi Yuliana 2011. Meningkatkan Ketrampilan Motorik Kasar Anak melalui kegiatan gerak dan lagu (online) Tersedia: pdfhttp://jurnal.upi.edu/file/22Sri hartin yuliana dewi-bl.pdf.(20 April 2015)

Suciati,Dkk. 2006 Belajar dan Pembelajaran 2. Jakarta:Universitas Terbuka

Suharsimi Arikunto, 2006 Prosedur Penelitian Suatu Pendekatan Praktik. PT Rineka Cipta, Jakarta

Supardi, 2009 Prinsip Dan Karakteristik Penelitian Tindakan Kelas, Jakarta, Depdiknas

Thomas Armstrong, 2002 Setiap Anak Cerdas Panduan Membantu Anak Belajar Dengan Memanfaatkan Multiple Intelligence-Nya. PT. Gramedia Pustaka Utama. Jakarta

Yayasan Pesantren Islam Al-Azhar. 2005 Petunjuk Pembelajaran Kelompok Bermain Islam Al-Azhar. Jakarta 